\title{
Effect of Kefiran and Milk Proteins Addition on the Rheological Behavior of Glucono- $\delta$-Lactone Induced Milk Gels
}

\author{
Georgia Dimitreli ${ }^{1}$, Stylianos Exarhopoulos ${ }^{1}$, Athanasios Goulas ${ }^{1}$, Kleio D. Antoniou ${ }^{1} \&$ Stylianos N. \\ Raphaelides $^{1}$ \\ ${ }^{1}$ Department of Food Technology, Alexander Technological Educational Institute of Thessaloniki, P.O. Box 141, \\ GR 57400, Thessaloniki, Greece \\ Correspondence: Georgia Dimitreli, Department of Food Technology, Alexander Technological Educational \\ Institute of Thessaloniki, P.O. Box 141, GR 57400, Thessaloniki, Greece. Tel: 30-231-001-3886. Fax: \\ 30-231-079-1375. E-mail: dimitrel@food.teithe.gr
}

$\begin{aligned} & \text { Received: November 29, } 2015 \text { Accepted: December 15, } 2015 \quad \text { Online Published: January 25, } 2016 \\ & \text { doi:10.5539/jfr.v5n1p121 }\end{aligned}$ URL: http://dx.doi.org/10.5539/jfr.v5n1p121

\begin{abstract}
The properties of kefiran as a texture modifier was evaluated providing new perspectives in understanding the rheology of fermented dairy products and the possibility of using this generally recognized as safe polysaccharide as an additive in dairy and other foods. For this purpose, the effect of kefiran, Sodium Caseinates $(\mathrm{SCN})$ and Whey Proteins Concentrates (WPC) addition on the rheological behavior of glucono- $\delta$-lactone (GDL) induced milk gels was evaluated. The acidified milk samples were prepared from homogenized and pasteurized full fat $(3.5 \%)$ bovine milk with or without the addition of kefiran, SCN and WPC at $1.5 \%$ concentration. The incubation temperature was set at $37^{\circ} \mathrm{C}$. According to the results, the incubation time required for the $\mathrm{pH}$ to reach 4.4 increased with increasing SCN and WPC concentration. Kefiran addition did not affect incubation time, however it did enhanced elasticity, apparent viscosity and thixotropic behavior of milk gels. The impact effect of kefiran on the rheological behavior of acid milk gels was more pronounced when compared to that of WPC, but lower to SCN effect. The protein matrix of GDL induced milk gels is governed by hydrophilic interactions in the presence of kefiran or WPC and by hydrophobic ones when SCN are added.
\end{abstract}

Keywords: kefiran, sodium caseinates, whey protein concentrates, glucono- $\delta$-lactone induced milk gels, apparent viscosity, viscoelastic properties

\section{Introduction}

The main polysaccharide, found in kefir and kefir grains, is kefiran. Kefiran accounts for almost half of the dry kefir grain weight (Abraham \& De Antoni, 1999) and together with milk proteins forms the matrix of the grains where the symbiotic microflora responsible for kefir formation is embedded. It is a water-soluble exo-cellular hetero-polysaccharide (EPS) produced from specific lactic acid bacteria (LAB) and consists of almost equal amounts of glucose and galactose (glucogalactan). In its structure a repeating pentasaccharide unit is observed that displays in random positions one to two monosaccharide branches (Kooiman, 1968; Micheli, Uccelletti, Palleshi, \& Crescenzi, 1999). Reports regarding its average molecular weight vary between $1 \times 10^{4}$ to $4 \times 10^{6} \mathrm{~g}$ $\mathrm{mol}^{-1}$ (Rimada \& Abraham, 2003; Yokoi, Watanabe, Fuji, Toba, \& Adachi, 1990).

The biological role of kefiran, similar to other bacterial EPS, is the protection of the bacterial cells from adverse conditions, occurring in their environment, and contrary to the biosynthesis of homo-polysaccharides (usually produced by single enzymatic reactions), the formation of hetero-polysaccharides like kefiran consists of several stages, where more than one enzymes are involved, and it depends on the bacterial carbohydrate metabolism and the growth achieved during fermentation (Duboc \& Mollet, 2001).

During the last 15 years EPS, similar to kefiran, produced by generally recognized as safe (GRAS) LAB have gained increased attention (Ruas-Madiedo \& de los Reyes-Gavilan, 2005). LAB are widely used in the dairy industry and their polysaccharide producing ability plays a particular role to the rheological properties, and consequently to a certain extent, the organoleptic characteristics of the resulting dairy products (Rimada \& Abraham, 2006). Multiple functional roles have been assigned to the presence of these heteropolysaccharides in food systems, such as enhancement of viscosity, suspension of particulates, inhibition of syneresis, product stabilization and emulsification (Duboc \& Mollet, 2001; Rimada \& Abraham, 2006; Vaningelgem, Zamfir, 
Adriany, \& De Vuyst, 2004). Additionally many other qualities have been allocated to polysaccharides like kefiran and some of these include therapeutic effects on asthma patients (Kwon et al., 2008) and antagonistic properties against virulence factors (Medrano, Hamet, Abraham, \& Perez, 2009).

The study of the rheological behavior of kefiran in acidified milk gel is of great scientific and commercial interest due to the inherent potential of the polysaccharide for use as texture modifier. So far, only Rimada and Abraham (2006) studied the effect of kefiran addition on the apparent viscosity and viscoelastic properties (derived by dynamic analysis) of acidified milk gels. Therefore, the aim of the present work was to study the effect of kefiran and milk protein addition on the rheological and viscoelastic behavior of acidified milk gels. Milk acidification has been simulated chemically by the use of glucono- $\delta$-lactone (GDL), instead of using starter cultures, so as to evaluate kefiran behavior without the presence of other polysaccharides produced by the lactic acid bacteria. Milk proteins (Sodium Caseinates-SCN and Whey Protein Concentrates-WPC) were used in order to compare their effect with that of kefiran. Incubation temperature was chosen so as to simulate the production of yogurt, the most popular fermented milk product all around the world. The rheological behavior of the samples was studied by the use of dynamic analysis and by the determination of the apparent viscosity of the samples.Viscosity is an important property of liquid-like products affecting their final quality and allowing the correct selection of equipment in the food industry. Dynamic analysis gives information about the energy stored and dissipated into a material.

\section{Materials and Methods}

\subsection{Materials}

Kefir grains derived from a household were used for kefiran production. SCN (MIPRODAN 30; Arla Food Ingredients, Viby J., Denmark) (moisture $\leq 6$; proteins 88-93.5; fat 1.5; ash 4; lactose 0.3) and WPC (Hellenic Protein S.A., Athens, Greece) (moisture $\leq 5$; proteins 80; fat 3.5; ash 3; lactose 10.4) were used as protein supplements.

\subsection{Fermentation Process}

The kefir grains were activated by successive sub-cultures in skimmed Ultra High Temperature (UHT) milk at $25^{\circ} \mathrm{C}$ using a grain inoculum ratio of $3 \%(\mathrm{w} / \mathrm{w})$ and until a $\mathrm{pH}$ of 4.4 was achieved within 24 hours of incubation (Cooled Incubator Series 8000, Termaks AS, Bergen, Norway). Fermentations aimed in activating the lactic acid bacteria so as to produce increased amounts of kefiran and to increase the mass of kefir grains.

\subsection{Isolation of Kefiran}

Following fermentation the grains were broken down in warm $\left(\right.$ at $\left.80^{\circ} \mathrm{C}\right)$ deionised water and the solution was then treated with trichloroacetic acid $(12 \% \mathrm{w} / \mathrm{w})$ for $24 \mathrm{~h}$ at $4^{\circ} \mathrm{C}$. Heating at $80^{\circ} \mathrm{C}$ assists the liberation of the cell-wall bound polysaccharide whereas treatment with trichloroacetic acid facilitates the precipitation and removal of proteins. The proteins and microbial cells were then removed via centrifugation at $10000 \mathrm{~g}$ (RC-3, Sorvall, France). Low molecular weight contaminants (e.g. sugars, amino acids, peptides, salts) were subsequently removed by 3 successive ethanol precipitation steps of the polysaccharide (1:2 vols of ethanol, at $4^{\circ} \mathrm{C}$ ) followed by centrifugation. The purified kefiran was then lyophilised to produce the final working preparation of the carbohydrate. The above described kefiran purification method is a combination of treatment steps as described by Rimada and Abraham (2003) and Ruas-Mediedo and de los Reyes-Gavilan (2005).

\subsection{Preparation of Acid Milk Gels}

The milk proteins (SCN and WPC) were added to the milk (before its heat treatment) at a concentration of $1.5 \%$ w/w and dissolved in a Grant GLS400 shaking water-bath (Grant Instruments Ltd, Cambridge, G.B.) under continuous stirring for $20 \mathrm{~min}$ at $35^{\circ} \mathrm{C}$. The kefiran was first diluted in deionised water (at a concentration of $25 \%$ $\mathrm{w} / \mathrm{w}$ ) under continuous stirring for $1 \mathrm{~h}$ at $80^{\circ} \mathrm{C}$ and then was added to the milk at a concentration of $1.5 \% \mathrm{w} / \mathrm{w}$ (resulting in a final $\mathrm{pH}$ value in acid milk gels around 4.4). The milk with or without the additives was heat-treated at $85^{\circ} \mathrm{C}$ for $15 \mathrm{~min}$ and then cooled down at $37^{\circ} \mathrm{C}$. The GDL was added into the milk at a concentration of $1.3 \% \mathrm{w} / \mathrm{w}$ and stirred for $2 \mathrm{~min}$. The samples were then incubated at $37^{\circ} \mathrm{C}$ until the $\mathrm{pH}$ value reached 4.4. The selection of incubation temperature, was made so as to simulate the production of yogurt. Particularly, the rate of acidification and the final incubation time is a function of incubation temperature. GDL is rapidly hydrolysed to gluconic acid at high temperatures. The temperature of $37^{\circ} \mathrm{C}$ resulted in a total incubation time of approximately 3-4.5 hours for all samples, which corresponds to the fermentation time of yogurt. Following incubation, the samples were mixed gently (20 times) and stored for $24 \mathrm{~h}$ before testing. All samples were produced in duplicate. 


\subsection{Determination of $\mathrm{pH}$}

A AGP353 ATCpH METER (EDT Instruments, Kent U.K.) was used for $\mathrm{pH}$ measurements during fermentation.

\subsection{Rheological Measurements}

The "Large" deformation tests can provide information about the structure of a material, while the "small deformation tests" can describe its viscoelastic behavior (study of the chemical bonds that comprise a protein network). Rheological measurements were made using a DMA rheometer (Bohlin C-VOR 150, Malvern Instruments Ltd, Worcestershire, UK), while a Peltier plate system $\left(-30\right.$ to $\left.+180^{\circ} \mathrm{C}\right)$ was used for temperature control. Rheological measurements were conducted in triplicate.

\subsubsection{Viscoelastic Properties of Acid Milk Gels}

The viscoelastic properties of acid milk gels were evaluated by the use of dynamic analysis. The DMA rheometer was equipped with a $40 \mathrm{~mm}$ diameter serrated plate so as no slip effects will occur during the measurements. The samples were placed in specially made aluminum sample containers (height $10 \mathrm{~mm}$ and diameter $40 \mathrm{~mm}$ ) that had also serrated surface. The upper plate was lowered so as to get in touch with the surface of the sample (approximately $1500 \mu \mathrm{m}$ ). Rheological measurements were performed at two different temperatures $\left(4^{\circ} \mathrm{C}\right.$ and $\left.25^{\circ} \mathrm{C}\right)$ aiming to reveal whether the chemical bonds of the acid gels, that contribute to its elasticity, have entropy or enthalpy nature.

A frequency sweep from 0.01 to $10 \mathrm{~Hz}$ was applied at strain deformation within the linear viscoelastic region $\left(1.104 \times 10^{-5}\right)$, previously determined by an amplitude test, The elastic $\left(\mathrm{G}^{\prime}\right)$ and viscous $\left(\mathrm{G}^{\prime \prime}\right)$ moduli as well as the loss tangent $(\tan \delta)$ of the samples were determined.

\subsubsection{Apparent Viscosity of Acid Milk Gels}

The determination of the apparent viscosity was made by the use of Bohlin equipped with a $4^{\circ}$ stainless steel cone. An amount of the sample was placed between the cone and the parallel plate-base of the rheometer. After lowering the cone to the measuring position (the gap was set to $150 \mu \mathrm{m}$ ), the excess sample was trimmed off the edges of the cone using a spatula. The strain rate applied was first increased from 0.1 to $100 \mathrm{~s}^{-1}$ and then decreased from 100 to $0.1 \mathrm{~s}^{-1}$, so as to study the thixotropic behavior of the samples. The determination of the apparent viscosity was made at $25^{\circ} \mathrm{C}$. From the flow curves of the samples the hysteresis area (the area between the upward and downward curves) $\left(\mathrm{A}_{0}\right)$ was calculated.

\subsection{Statistical Analysis}

The statistical analysis of the experimental data was performed using one-way (incubation time and $\mathrm{A}_{0}$ ) or two-way (viscoelastic properties) Anova, while the Tukey multiple comparison test determined whether statistically significant differences occurred among means. The Minitab 16.0 statistical software was used for the statistical analysis.

\section{Results and Discussion}

\subsection{Incubation Time}

According to one-way Anova, the incubation time was significantly affected by supplement addition $(\mathrm{p}<0.001)$. As it can be seen in Figure 1, the sample made with SCN exhibited the highest incubation time, followed by the sample made with WPC, while the sample with kefiran addition exhibited the same incubation time with the control sample. Tukey test confirmed the order of samples presented in Figure 1. The increase in fermentation time with SCN and WPC addition is due to the increased buffering capacity of the system because of the presence of proteins. Both caseins and whey proteins possess high buffering capacity resulting in more lactic acid production in order to reduce the $\mathrm{pH}$ of the samples. However, caseins have higher buffering capacity when compared to whey proteins (Salaün, Mietton, \& Gaucheron, 2005), exhibiting the highest incubation time of all samples. Kefiran, as expected, did not affect the incubation time of GDL induced milk gels.

\subsection{Viscoelastic Properties}

The $\mathrm{G}^{\prime}$ and $\tan \delta$ were significantly affected by supplement addition $(\mathrm{p}<0.001)$ and temperature during rheological measurements $(\mathrm{p}<0.001)$, as well as by their interaction $(\mathrm{p}<0.001)$ (Figures 2 and 3 , respectively). The control sample and the sample made with SCN addition exhibited increased elasticity (increased values of $\mathrm{G}^{\prime}$ ) with increasing temperature (Figure 2). This is an indication that the protein matrix formed during acidification is governed by hydrophobic interactions. Caseins have both hydrophilic and hydrophobic groups. Among caseins, $\beta$-casein is the most hydrophobic one, followed by $\alpha_{\mathrm{s} 1}{ }^{-}$and $\alpha_{\mathrm{s} 2}$-caseins. The most hydrophilic casein, $\kappa$-casein, is located at the surface of the casein micelles so as to allow them to be in colloidal dispersion 
in the milk serum (Walstra, Wouters, \& Geurts, 2006). During milk acidification the colloidal calcium phosphate dissociates from the casein micelles into the milk serum reducing their size and liberating the monomers of caseins (Lucey, 2004). Thus, the hydrophobic caseins have the opportunity to interact each other, contributing to the elasticity of the final matrix. The caseins predominate in milk (control sample) at a percentage of $80 \%$ of the total proteins (Walstra et al., 2006), while the addition of SCN increases the number of hydrophobic groups present at the system. At both cases it seems that the hydrophobic interactions dominate.

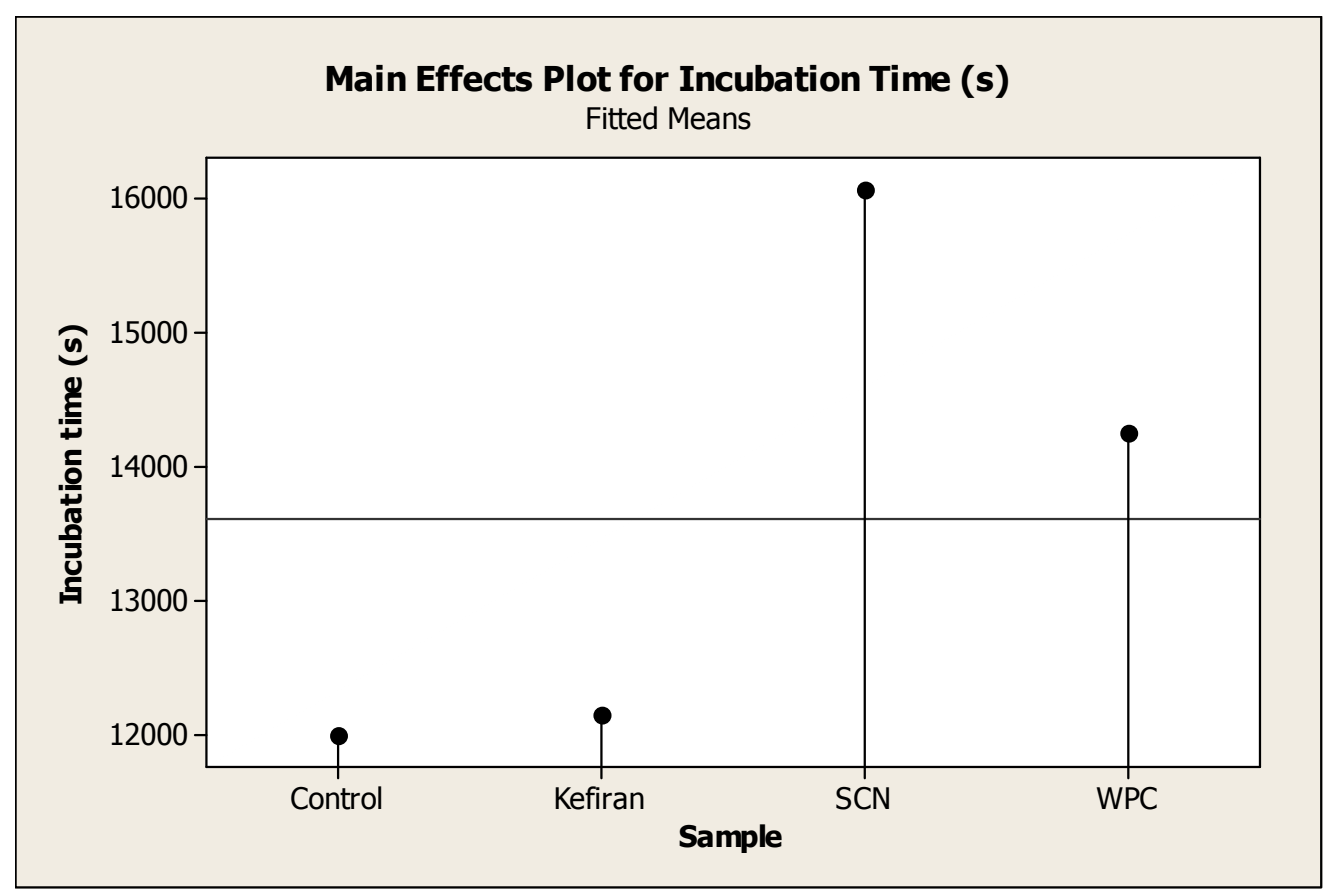

Figure 1. Effect of milk proteins (Sodium Caseinates-SCN and Whey Protein Concentrates-WPC) and kefiran addition on the incubation time of acid milk gels

In contrast, samples made with WPC and kefiran resulted in reduced elasticity with increasing temperature (Figure 2). Denatured WPC have a hydrophilic nature and increased water holding capacity (Chandan, 2006). During heat-treatment of milk WPC denature and form complexes with $\kappa$-casein (Lucey, Munro, \& Singh, 1998), increasing the water holding capacity of the gel (Chandan, 2006) and the number of hydrophilic groups existing. Thus, the addition of WPC into the milk system increases the hydrophilic nature of the protein matrix formed.

The decrease in $G^{\prime}$ values of the sample made with kefiran addition with increasing temperature (Figure 2) indicates that the interactions formed between kefiran and milk proteins are hydrophilic. These interactions might be electrostatic or hydrogen bonding. According to Doublier, Garnier, Renard and Sanchez (2000), electrostatic interactions between oppositively charged proteins and polysaccharides are, in most cases, the prevalent primary interactions in associative mixed biopolymer systems. The authors also reported that in some examples primary macromolecule interactions can be included by hydrogen bonding. In both cases the interactions formed have hydrophilic nature. Thus, the attractive interactions between negatively charged polysaccharides and the positively charged proteins (Duboc \& Mollet, 2001; Girard \& Schaffer-Lequart, 2007) might be responsible for the increased elasticity at $4^{\circ} \mathrm{C}$ of the sample made with kefiran addition when compared to control sample (Figure 2). The final $\mathrm{pH}$ values of the samples (4.4) are below the isoelectric point of milk proteins that is 4.6 for caseins and 5.2 for whey proteins (Lucey, Tamehana, Singh, \& Munro, 1998) resulting in positively charged protein molecules. These interactions predominate at the protein matrix resulting in decreased elasticity with increasing temperature.

The elastic behavior predominated (the values of $\tan \delta$ was below 1.0) at all samples, besides control, at $4^{\circ} \mathrm{C}$ (Figure 3). This means that milk proteins as well as kefiran contribute to the elasticity of the gel. Increasing the temperature of rheological measurements enhanced the liquid-like behavior of the samples made with WPC and kefiran. The increased liquid-like behavior of the samples is due to their hydrophilic nature. The increase was more pronounced at WPC (due to their increased water holding capacity), attributing them the most liquid-like 
behavior. The control sample and the sample prepared with SCN increased further their solid-like behavior with increasing temperature, due to the hydrophobic interactions of caseins that govern the protein matrix that is being formed.

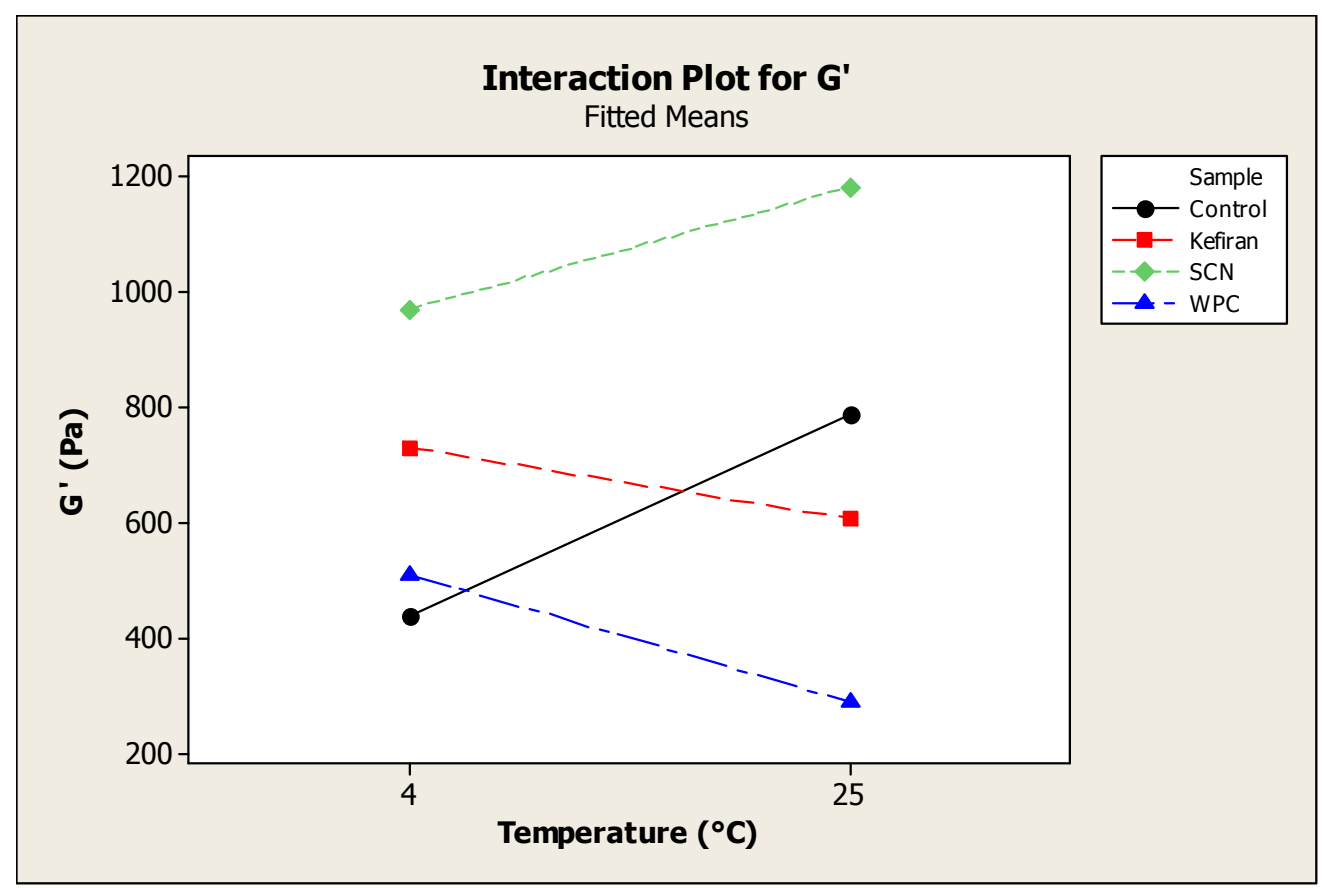

Figure 2. Effect of supplement addition (Sodium Caseinates-SCN, Whey Protein Concentrates-WPC and kefiran) and temperature (during rheological measurements) on the elastic modulus ( $\left.\mathrm{G}^{\prime}\right)$ of acid milk gels

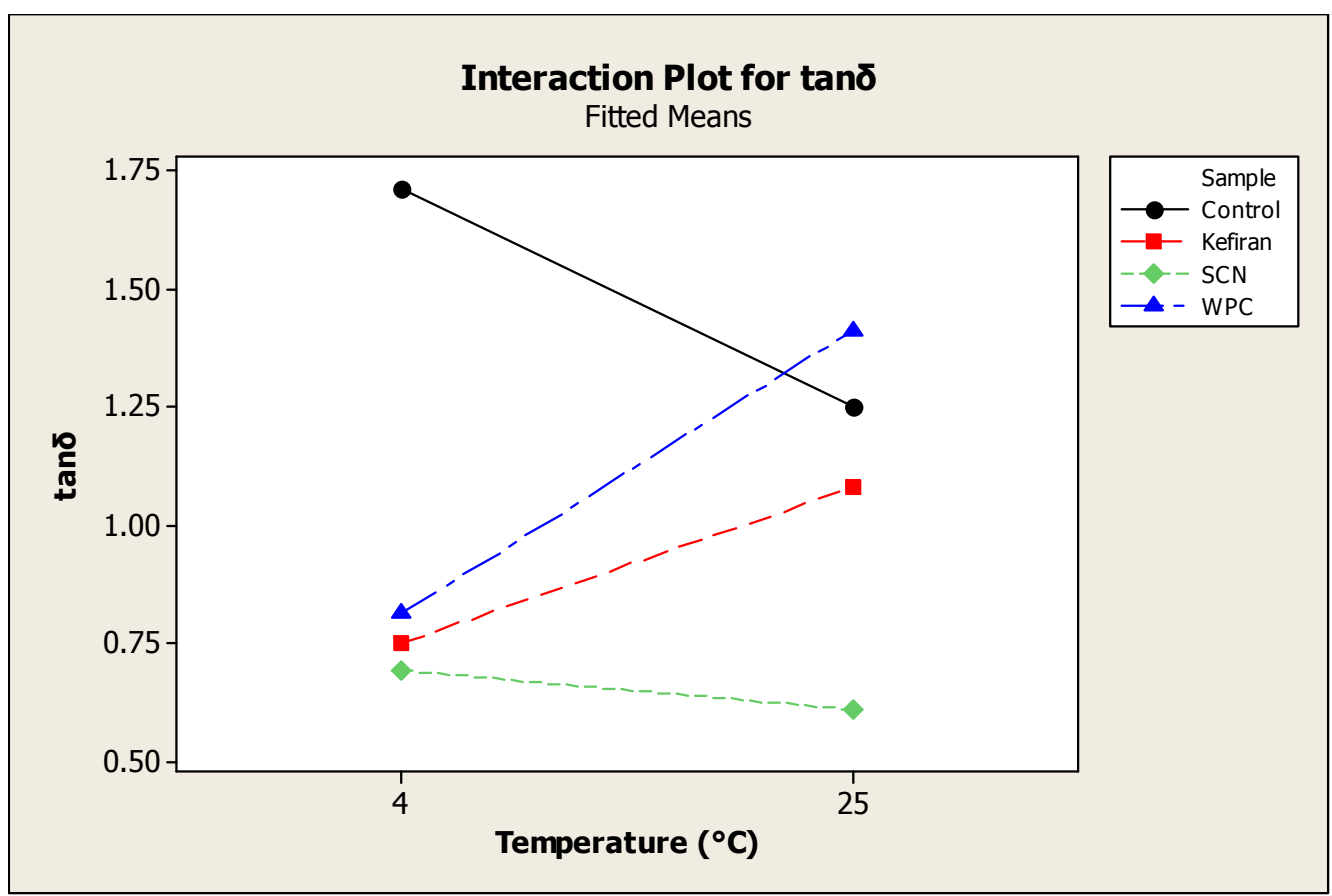

Figure 3. Effect of supplement addition (Sodium Caseinates-SCN, Whey Protein Concentrates-WPC and kefiran) and temperature (during rheological measurements) on the $\tan \delta$ of acid milk gels 


\subsection{Apparent Viscosity}

The flow curves of GDL induced acid milk gels are shown in Figure 4. As it can be seen, the sample with SCN addition exhibited the maximum increase in apparent viscosity, followed by the sample prepared with kefiran. WPC addition slightly increased the apparent viscosity of the gel (compared with control sample). Caseins exist in milk system in the form of complexes (micelles), while whey proteins are dispersed in the whey as monomers (Chandan, 2006). This means that the aggregates of caseins have increased hydrodynamic volume and thus increased resistance in the application of stress. Kefiran interacts with milk proteins resulting in the formation of aggregates that have also increased hydrodynamic volume and increased resistance to flow. However, these aggregates are smaller when compared to that formed in the presence of caseins.

It is evident from the flow curves of the samples that the acid milk gels have thixotropic behavior that is their apparent viscosity is reduced with shear rate as well as with time increase. This means that the bonds or interactions formed during acidification are continuously destroyed (a continuously breakdown of the structure) by the application of shear. A measure of the thixotropic behavior is the area enclosed between the upward and downward curves $\left(\mathrm{A}_{0}\right)$.

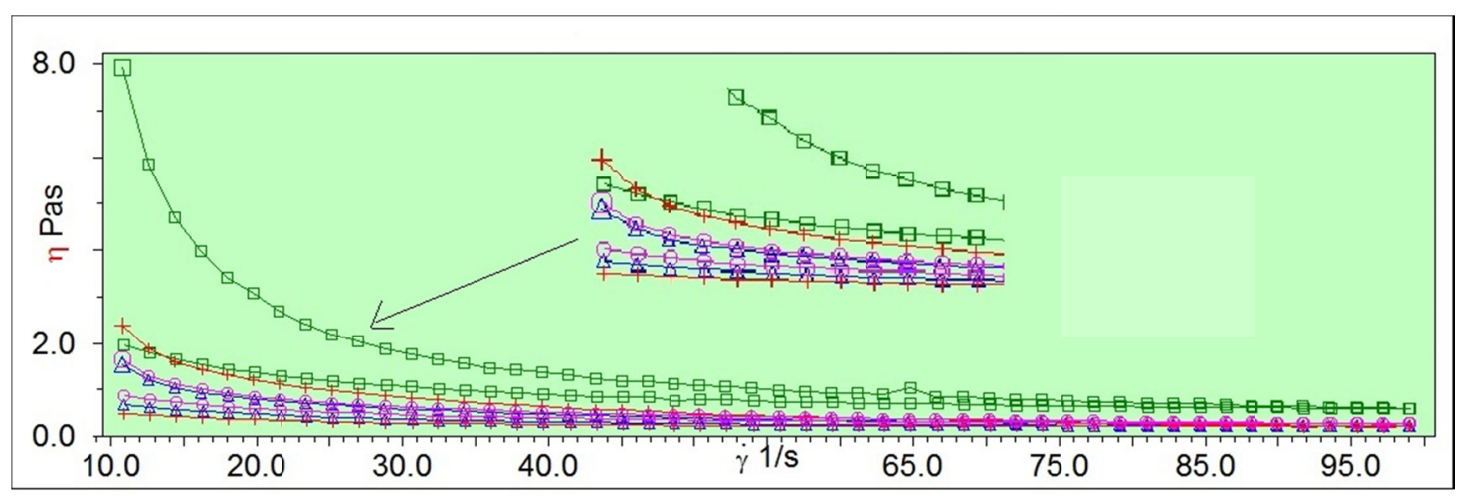

Figure 4. Effect of milk proteins (Sodium Caseinates-SCN and Whey Protein Concentrates-WPC) and kefiran addition on the apparent viscosity $(\eta)$ of acid milk gels (SCN: green line; kefiran: red line; WPC: pink line; control: blue line). Where $\dot{\gamma}$ is the strain rate

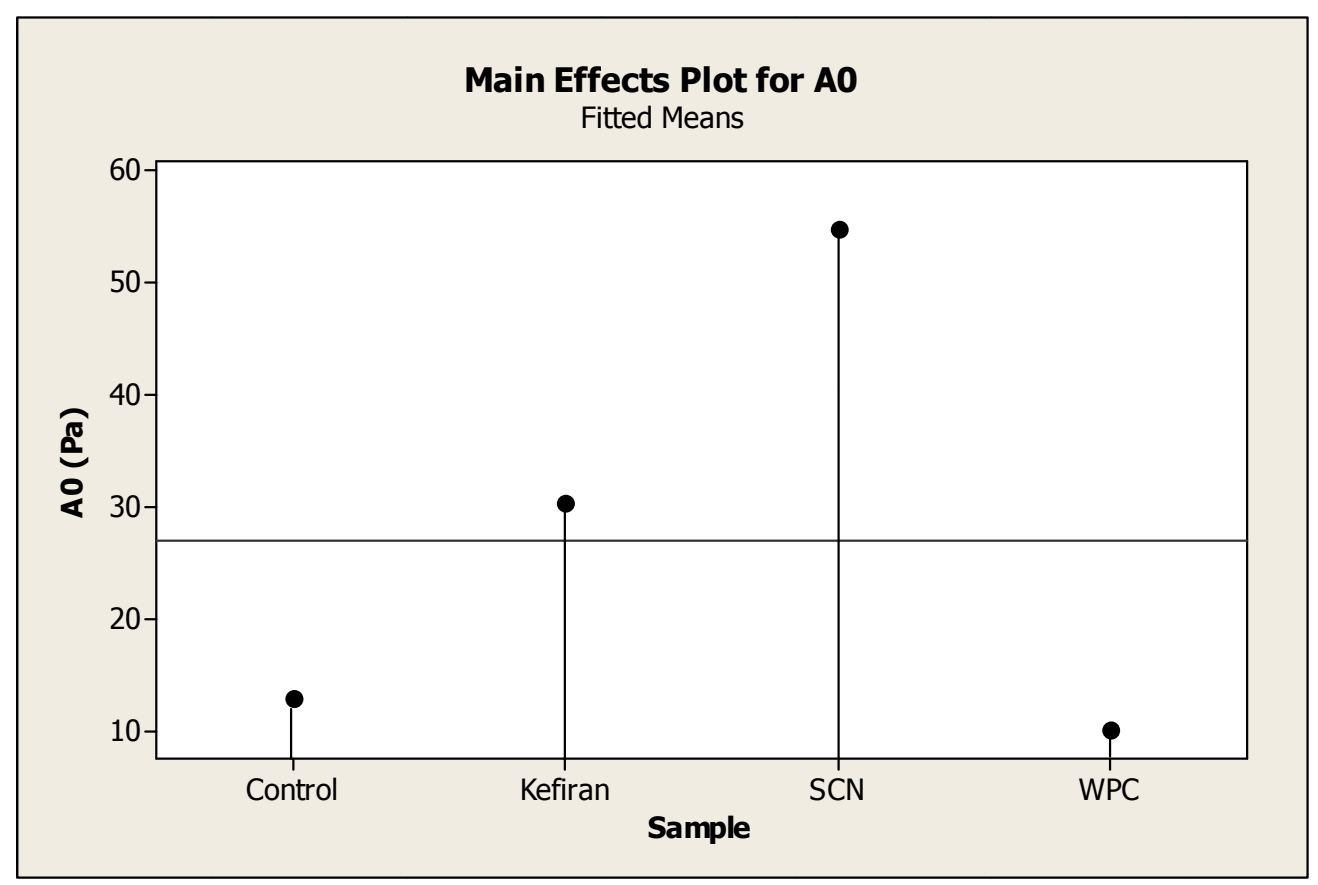

Figure 5. Effect of milk proteins (Sodium Caseinates-SCN and Whey Protein Concentrates-WPC) and kefiran addition on the hysteresis area $\left(\mathrm{A}_{0}\right)$ of acid milk gels 
According to one-way Anova, the $\mathrm{A}_{0}$ was significantly affected by supplement addition $(\mathrm{p}<0.001)$. As it can be seen in Figure 5, SCN addition resulted in the highest thixotropic behavior, followed by kefiran addition, while WPC exhibited the lowest thixotropic behavior even from the control sample. The Tukey test showed that $\mathrm{A}_{0}$ increased in the following order: WPC $<$ control $<$ kefiran $<$ SCN. Addition of SCN, kefiran or WPC into the milk system increases the number of interactions formed. When the molecules are linked together by weak forces the interparticle linkages are broken, when the hydrodynamic forces during shear are sufficient high. This results in reduction in size of the structural units that, in turn, offers lower resistance to flow during shear (Rao, 1999). Thus interactions between casein molecules, as well as kefiran and milk proteins are weaker when compared to those between whey proteins or whey proteins and caseins.

\section{Conclusion}

Kefiran, the polysaccharide derived from kefir grains, can be used as a texture modifier, as it enhanced elasticity, apparent viscosity and thixotropic behavior of GDL induced milk gels. Particularly, the impact effect of kefiran on the rheological behavior of acid milk gels was more pronounced when compared to that of WPC but lower to SCN effect. In the presence of kefiran or WPC the protein matrix of milk gels is governed by hydrophilic interactions, and by hydrophobic ones when SCN are added. Kefiran addition did not affect incubation time.

\section{Acknowlegments}

This research has been co-financed by the European Union (European Social Fund - ESF) and Greek national funds through the Operational Program "Education and Lifelong Learning" of the National Strategic Reference Framework (NSRF) - Research Funding Program: ARCHIMEDES III. Investing in knowledge society through the European Social Fund. The authors thank Mr Kleona Tsakmakidi (Hellenic Protein S.A.) for the supply of the SCN.

\section{References}

Abraham, A. G., \& De Antoni, G. L. (1999). Characterization of kefir grains grown in cows' milk and in soya milk. Journal of Dairy Research, 66, 327-333.

Doublier, J. L., Garnier, C., Renard, D., \& Sanchez, C. (2000). Protein-polysaccharide interactions. Current Opinion in Colloid \& Interface Science, 5, 202-214. http://dx.doi.org/10.1016/S1359-0294(00)00054-6

Duboc P., \& Mollet B. (2001). Applications of exopolysaccharides in the dairy industry. International Dairy Journal, 11, 759-768. http://dx.doi.org/10.1016/S0958-6946(01)00119-4

Girard, M., \& Schaffer-Lequart, C. (2007). Gelation and resistance to shearing of fermented milk: Role of $\begin{array}{lllll}\text { exopolysaccharides. International Dairy } & \text { Journal, } & \text { 17, }\end{array}$ http://dx.doi.org/10.1016/j.idairyj.2006.08.007

Kooiman P. (1968). The chemical structure of kefiran, the water-soluble polysaccharide of the kefir grain Carbohydrate Research, 7, 200-211. http://dx.doi.org/10.1016/S0008-6215(00)81138-6

Kwon, O. K., Ahn, K. S., Lee, M. Y., Kim, S. Y., Park, B. Y., Kim, M. K., \& Lee, H. K. (2008). Inhibitory Effect of Kefiran on Ovalbumin-induced Lung Inflammation in a Murine Model of Asthma. Archives of Pharmacal Research, 31(12), 1590-1596. http://dx.doi.org/ 10.1007/s12272-001-2156-4

Lucey, J. A., Tamehana, M., Singh, H., \& Munro, R. A. (1998). Effect of interactions between denatured whey proteins and casein micelles on the formation and rheological properties of acid skim milk gels. Journal of Dairy Research, 65, 555-567.

Medrano, M., Hamet, M. F., Abraham, A. G., \& Perez, P. F. (2009). Kefiran protects Caco-2 cells from cytopathic effects induced by Bacillus cereus infection. Antonie van Leeuwenhoek, 96, 505-513. http://dx.doi.org/10.1007/s10482-009-9366-z

Micheli, L., Uccelletti, D., Palleshi, C., \& Crescenzi, V. (1999). Isolation and characterisation of a ropy Lactobacillus strain producing the exopolysaccharide kefiran. Applied Microbiology and Biotechnology, 53, 69-74. http://dx.doi.org/10.1007/s002530051616

Rao, M. A. (1999). In M. A. Rao (Ed.), Rheology of fluid and semisolid foods, Principles and applications (pp. 1-22). Maryland: Aspen Publishers, Inc.

Rimada, P. S., \& Abraham, A. G. (2003). Comparative study of different methodologies to determine the exopolysaccharide produced by kefir grains in milk and whey. Lait, 83, 79-87. http://dx.doi.org/10.1051/lait:2002051

Rimada, P., \& Abraham, A. (2006). Kefiran improves rheological properties of glucono- $\delta$-lactone induced skim 
milk gels. International Dairy Journal, 16, 33-39. http://dx.doi.org/10.1016/j.idairyj.2005.02.002

Ruas-Madiedo, P., \& de los Reyes-Gavilan, C. G. (2005) Invited review: methods for the screening, isolation, and characterization of exopolysaccharides produced by lactic acid bacteria. Journal of Dairy Science, 88, 843-856. http://dx.doi.org/10.3168/jds.S0022-0302(05)72750-8

Salaün, F., Mietton, B., \& Gaucheron, F. (2005). Buffering capacity of dairy products. International Dairy Journal, 15, 95-109. http://dx.doi.org/10.1016/j.idairyj.2004.06.007

Vaningelgem, F., Zamfir, M., Adriany, T., \& De Vuyst, L. (2004). Fermentation conditions affecting the bacterial growth and exopolysaccharide production by Streptococcus thermophilus ST 111 in milk-based medium. Journal of Applied Microbiology, 97, 1257-1273.

Walstra, P., Wouters, J. T. M., \& Geurts, T. J. (2006). Dairy Science and Technology (2nd Ed.). Boca Raton, London, New York: Taylor \& Francis, CRC Press.

Yokoi, H., Watanabe, T., Fuji, Y., Toba, T., \& Adachi, S. (1990). Isolation and Characterization of Polysaccharide-Producing Bacteria from Kefir Grains. Journal of Dairy Science, 73, 1684-1689. http://dx.doi.org/10.3168/jds.S0022-0302(90)78843-1

\section{Copyrights}

Copyright for this article is retained by the author(s), with first publication rights granted to the journal.

This is an open-access article distributed under the terms and conditions of the Creative Commons Attribution license (http://creativecommons.org/licenses/by/3.0/). 